\title{
The Effects of R\&D Intensity and Tax Incentives on Firms Growth of PIGS Countries
}

\author{
Markéta Šeligová*
}

\begin{abstract}
:
The aim of this paper is to evaluate the effects of R\&D intensity, R\&D investment and tax incentives on firms' growth in Portugal, Italy, Greece and Spain from 2002 to 2014. Another ambition of this paper is to identify which selected factors affected firms' growth. The effect of variables such as the R\&D intensity, generosity of tax incentives, capital intensity, profitability, firm size and firm sales was tested. Using panel regression analysis a positive influence R\&D intensity and generosity of tax incentives at firms' growth was recorded.
\end{abstract}

Key words: Firms growth; R\&D Intensity; Tax subsidies.

JEL classification: H20, H25, O32.

\section{Introduction}

The aim of this paper is to evaluate the effects of R\&D intensity and tax incentives on firms' growth in Portugal, Italy, Greece and Spain from 2002 to 2014. Another target of this paper is to identify which selected factors affecting firm' growth. This study aims at understanding the simultaneous influence of R\&D investment and R\&D tax incentives on firms' growth, for different technological and knowledge-intensity industries. The first chapter includes an introduction and literature review. The second part of this paper includes a methodology, using date and purpose of the panel regression analysis. This chapter includes an overview of variables and characteristics of the data used. The third part of the paper is focused on the results of estimating panel regression analysis and their comments. This chapter is focused on the selected factors influenced the firms' growth PIGS countries from 2000 to 2014. Attention will be given to selected indicators: variables such as the $R \& D$ intensity, generosity of tax incentives, capital intensity, profitability, firm size and firm sales.

Countries have introduced the R\&D tax incentives at different points in time and have shaped them in various ways. Even for such a generic policy instrument, the specific design, type and number of R\&D tax incentives differ substantially across countries. These differences could be divided into three main categories:

\footnotetext{
Markéta Šeligová; Silesian University in Opava, School of Business Administration in Karviná, Department of Finance and Accounting, Univerzitní nám. 1934/3, 73340 Karvina, Czech Republic, <seligova@opf.slu.cz>.

The article is processed as an output of a research project Financial instruments of public support for research and development in the European Union registered by the Grant Agency under the registration number SGS/17/2015.
} 
- scope of the policy, including the type of $\mathrm{R} \& \mathrm{D}$ tax incentive and costs covered

- targeting of specific groups of firms, according to their size, age, region, etc.

- organization, including administrative practices and generosity

The scope of an R\&D tax incentive defines how the instrument works conceptually: how the incentive is applied and what type of expenditure and income qualify.

The incentive can be "volume-based" and apply to all R\&D activity or it can be "incremental" and only apply to new R\&D activity. The tax benefit can refer to different sorts of R\&D expenditures. Usually, an R\&D tax incentive applies to specific inputs that are used in $R \& D$ processes (incentive base) and requires some degree of novelty for the intended outcome (requirement of novelty) (Straathof et al., 2014).

Every scheme might have some particularities, but broadly four approaches can be distinguished. $R \& D$ tax incentives can be applied in at least four ways (Straathof et al., 2014):

- tax credits,

- enhanced allowances,

- accelerated depreciation,

- reduced rates.

Tax credits ( $R \& D$ expenditure): tax credit decreases the corporate income tax rate a firm has to pay. Rate can be applied to either corporate tax, payroll tax paid for $\mathrm{R} \& \mathrm{D}$ workers or personal income in case the incentive is targeted to selfemployed.

Enhanced allowances (R\&D expenditure): an enhanced allowance effectively decreases the base amount that is taxed by allowing to inflate the $R \& D$ expenditure base.

Accelerated depreciation ( $R \& D$ expenditure): accelerated depreciation scheme permits to depreciate the purchased fixed assets at higher rates in the first year of the asset's life. This allows, therefore, to decrease the overall taxable income in the specific periods.

Reduced corporate tax rate (IP income): reduced corporate tax rate on intellectual property income are an outcome related incentive. It reduces the corporate income that firms pay on commercialization of innovative products that are protected by intellectual property rights.

$R \& D$ tax incentives also differ by the nature of the incentive base. In particular, some of the schemes are related to the income generated by R\&D rather than its 
costs. R\&D tax incentives that are based on costs can be targeted to different expenditure sub-categories (Straathof et al., 2014). They are as follows:

- R\&D costs: this category includes a variety of eligible expenditures. Some countries limit the type of costs and expenditures that qualify as $R \& D$ expenditures to machinery and equipment. Other countries restrict the qualifying expenditures to R\&D costs that are carried out domestically.

- R\&D wages: incentive is based on wage bill tax (payroll-withholding tax)

- IP expenditures: this category includes the costs and expenditure for acquiring patents, investments in intangible assets, or the purchase of new technologies

- R\&D and IP expenditures: this is a combination of the first two categories

- Discretionary: a limited number of countries provide lower corporate tax rates for qualified R\&D firms as such

- IP income: incentive is applied to profits gained from commercialization of products that are protected by intellectual property rights

The category R\&D costs and expenditures can be divided into different subcategories. For instance, in some countries only R\&D wages are eligible costs, while other countries employ a much broader definition including buildings and overhead costs (Straathof et al., 2014).

Research and development (R\&D), including innovation is important for economic growth, competitiveness and growing standards of living. We must pay much more attention to this part of the economy. Every single country finances its $R \& D$ in a different way. Some of the countries spend a huge amount of money on its $R \& D$ and on the other hand there are other countries that spend less money and therefore they put less emphasis on their research. Research in the developed societies has an irreplaceable position. Science, technologies, innovations are changing and transforming and they are adapting to the current challenges as well as other areas of social life. These new values strengthen the competitiveness of the economy, which also represents one of the government's priorities. Tax policy is a traditional mechanism through which government influences the cost of private sector $R \& D$. Measuring the effective $R \& D$ subsidy should incorporate the relevant rate of corporate income tax; rates of depreciation for different classes of expenditure as well as explicit incentive schemes such as augmented deduction allowances, credits and rebates. The structure of public support to corporate $R \& D$ has been rapidly changing over the last decade (Elschner and Ernst, 2008).

Two major developments could be observed in a significant number of countries: On the one hand, public funds for basic $R \& D$ performed by universities are increasing and linked via additional stimuli for technology transfer (e.g. grants for collaborative $R \& D$ projects) to corporate $R \& D$ activities. On the other hand, 
government R\&D policies are increasingly oriented towards market signals and competition in order to minimise the potential distortions in the firm's choice of $R \& D$ projects while increasing the overall level of $R \& D$ in combination with relatively low compliance costs. This led several countries introduce tax-based R\&D incentives in addition to direct subsidies. A growing number of countries support a significant share of private $R \& D$ via tax incentives. (Elschner and Ernst, 2008).

PIGS countries have several common denominators. The high deficits of the current account (trade with foreign countries), low competitiveness and in comparison with other countries of the Eurozone alarming unemployment. In addition, PIGS countries are highly indebted. They are different particularly as regards the development of the crisis. While Portugal, Greece and Italy grew less than the EU average and were not able to compete with advanced economies, Spain fared. Before the crisis showed very successful years, accompanied by government budget surpluses. For this reason, it would be very interesting and useful to know the effects of $\mathrm{R} \& \mathrm{D}$ intensity, $\mathrm{R} \& \mathrm{D}$ investment and tax incentives on firms' growth in the PIGS countries. Countries may use tax incentives in the form tax credits, enhanced allowances, accelerated depreciation and reduced corporate tax rate and to take advantage of these forms of tax incentives. For example, countries can reduce the tax base by reducing corporate taxes.

Undoubted benefit of this contribution will be finding the factors that affect the firms growth in Portugal, Italy, Greece and Spain. The vector of explanatory variables will include variables such as the R\&D intensity, generosity of tax incentives, capital intensity, profitability, firm size and firm sales. The outcome will determine which variables affect the firms growth and which variables had no effect on the firms' growth. It is quite evident that a very important task is to fill a vector of explanatory variables and so that we can tap into as many factors that could affect the firms growth in PIGS countries. For this purpose, it will be needed to process a detailed literature review. 


\section{Literature Review}

Stiglitz (1969) and Hall \& Mairesse (1995) think that R\&D activities can improve firm productivity via a variety of channels. By applying new knowledge and new technology, firms can update manufacturing processes, improve product quality, lower costs and create more intermediate and final products. This argument is consistent with studies of Hall (1987), which found a positive impact of R\&D investments on 1-year employment growth of US firms. On the other hand, Cohen and Levinthal (1989) define R\&D as a source of new information feeding the innovation discovery, but also as a way to develop the firm's ability to exploit external knowledge. Cohen and Levinthal (1990) found in their further studies that R\&D investment increases absorptive capacity. Absorptive capacity defined as the capacity to absorb knowledge created from the relationships formed with agents outside the firm, as well as the capacity to use that knowledge to increase firm's performance. $R \& D$ can promote employment. R\&D becomes an essential factor to boost productivity. Another significant benefit of R\&D to the economy lies in its spillover potential. Specifically, when a firm sells new products or new intermediate products to other firms at relatively low prices, it generates "pecuniary spillover". On the other hand, when the new technology, created from a firm's R\&D, is shared by others, it generates "non-pecuniary spillover" effects. This is consistent with studies of Benhabib \& Jovanovic (1991). The spillover effect can definitely help to improve the productivity and the welfare of the economy. Therefore, $\mathrm{R} \& \mathrm{D}$ activities can positively boost the growth of individual firms and the economy as a whole.

Warda (2009) concluded that R\&D tax concession policies (as one of the main tax policies to promote $R \& D$ investment inside firms) are an effective mechanism to increase the levels of investment in technology. The mechanisms linking $R \& D$, innovation success and firm performance at the firm level are largely indebted to the Schumpeterian endogenous growth representation, according to which firms strive to innovate so that they can enjoy monopoly rents (Aghion and Howitt 1992).

Cefis and Orsenigo (2001) found that innovation persistence tends to increase with firm's size. However, they found the relationship between firms' size and persistence to be country-specific and complex. Greenhalgh et al. (2001) found a positive impact of R\&D investments on 1-year employment growth of UK firms.

Delmar et. al. (2003) considered firms' growth as phenomenon which depends on different variables. He thinks that part of this complexity is due to different conceptions of firm's growth. On the one hand, scholars consider four different types of firm growth: organic growth, creation of new firms, concentration of existing firms (mergers, acquisitions) and growth through innovation and diffusion of new products and pro-cesses. Delmar et. Al. (2003) and Wong et al. (2005) 
considers that the nature of firm growth is a heterogeneous, complex and dynamic process that involves economic, social and cultural factors. On the other hand, Coad (2009) claimed that analysis of firm growth may have two faces: quantitative ('how much') and qualitative ('how').

Del Monte and Papagni (2003) and Lee (2009) concluded that the effect of R\&D intensity on firms' growth varies according to the sector: on the one hand, firms with limited technological intensity find that innovations resulting from $R \& D$ investment are relatively easily copied by competitors and are not a barrier to new firms entering the market; on the other hand, in sectors with high technological intensity, characterised by high investment in $\mathrm{R} \& \mathrm{D}$ and sizeable economies of scale, R\&D investment can function as an effective barrier to new firms entering the market. Therefore, $R \& D$ investment can positively influence the growth of firms' belonging to high-tech sectors. This fact is consistent with studies of Hölzl (2009) who found that R\&D intensity has a positive influence on firm 1-year growth rates in countries closer to the technology. This fact is also confirmed by studies of Hölzl and Friesenbichler (2010) who found that high-growth firms present a higher R\&D intensity than other firms only in countries close to the technology frontier. Coad and Rao (2010) found out that there exists an empirical evidence that a fixed share of sales are invested in R\&D for a sample of listed US manufacturing firms. The relationship between innovation and firm's growth is complex as at the one hand (product) innovation could affect profits via increased sales at constant profit margins while at the other hand (process) innovation could also directly affect profit margins.

Huergo and Jaumandreu (2004) and Rochina et al. (2010) further improved our understanding of delayed or long-term effects of innovation on economic performance by using analysis of Spanish panel data. They found the effect of process innovations on productivity growth to somehow persist over time. In addition, they found that this effect is expected to be larger in case there is persistence in the firm's innovative behaviour.

Varadzin (2004) argued that what makes the research and development profitable looks like a temporary monopoly on the market. The good thing for the economy is that if one company innovates and spends its money on R\&D, other companies might get inspired and follow such a process. Science and research is becoming a generator of positive externalities. From the empirical perspective the analysis regarding innovation and $\mathrm{R} \& \mathrm{D}$ effects on firm's growth are also extensive. In general, the empirical evidence notes a positive effect between firm growth and innovation that differs according to firm characteristics, the nature of market selection and the geographical environment.

Castro (2006) thinks that tax policies have a permanent impact on the economic growth rate. This fact extends studies of Coad and Rao (2008) reveal that the 
positive impact of innovative activities on firm's growth is concentrated among the fastest growing firms, while for others it can be negative. On the other hand, Peková (2008) believes that the important economic variables such as economic growth, unemployment or companies competitiveness are largely dependent on a research and development results.

Huergo and Moreno (2011) analysed the relationship among R\&D expenditures, innovation and productivity growth taking into account the persistence of firm's behaviour. Their results show that the omission of innovation persistence leads to an overestimation of the current impact of innovations on productivity growth. However, the presence of persistence in technological inputs and outputs entails current $R \& D$ activities having long-run effects on a firm's productivity.

Lian (2011) provides evidence at the firm's level regarding the relationship between R\&D investment and firm growth, with respect to the influence of financial constraints, government support and involvement of financial intermediaries and insurers. The data are derived from the survey of 609 high tech firms in China from 2007 to 2009. The results show that R\&D expenditure can significantly enhance firm's growth. The effects of government support show a "crowding out" effect on firm level R\&D activities. Firms facing financial constraints tend to suppress their R\&D expenditure, resulting in significantly lower returns from $R \& D$. The results demonstrate that investment in $R \& D$ can significantly enhance firms' growth potential, but with some lags, rather than concurrently. Furthermore, with more financial constraints limits, firms tend to reduce $R \& D$ expenditure that eventually leads to lower returns from $R \& D$. It was found that investment in R\&D can significantly enhance firms' growth potential, but with some lags, rather than concurrently. There was also found a positive impact of government support on firm's growth resulting from R\&D activities. Moreover, firms' financial constraints status has an important role in shaping R\&D activities, in that firms facing severe financial constraints tend to reduce $R \& D$ expenditure, resulting in lower returns from $R \& D$.

The American market was examined by Demirel and Mazzucato (2012) who were exploring how innovation affects firm growth in US pharmaceutical firms from 1950 to 2008. They found that the positive impact of R\&D on firm growth is highly conditional upon a combination of firm characteristics such as firm's size, patenting and persistence in patenting. They found that the positive impact of R\&D on firm's growth is highly conditional upon a combination of firm's characteristics such as firm's size, patenting and persistence in patenting. For large pharma firms, $R \& D$ affects firm's growth positively with the exception of those that do not patent. On the other hand, for small firms, R\&D boosts growth for only a small subset of firms: namely those that patent persistently for a minimum of 5 years. 
García-Manjón and Romero-Merino (2012) sum up that it is expected that the creation of knowledge will influence the development of the firm in terms of sales growth, profitability or employment creation, causing an expected positive relationship between R\&D investment and a firm's growth. They presented a model of endogenous firm's growth with $R \& D$ investment as one of the main mechanisms of growth. They found a positive effect of R\&D intensity on the sales growth by using OLS, quantile regressions, and GMM system estimators for a sample of 754 European firms for the 2003-2007 period. They also found that this association is more intense in high-growth firms and is especially significant when referring to high-technology sectors.

Triguero-Cano et al. (2012) analysed the role of innovation output persistence on employment growth. Using a GMM system estimator they showed that process innovation has a positive effect on employment while the effect of product innovation is positive but insignificant. They also found that the compensation effect of process innovation to increase over time. Similar issues are also dealt with studies Triguero and Córcoles (2014) considered the effect of the persistence of innovation on employment in Spanish manufacturing firms during the period 1990-2008. They use a GMM-system estimation to study the importance of persistence of product and process innovation on employment growth. The empirical results indicate that process innovation measures show a positive effect on employment while the effect of product innovation is positive but not significant.

Wang (2013) examined the effect of publicly-supported research and development (R\&D) subsidies on firm growth in Taiwan. The empirical models were estimated using firm-level balanced panel data for the years 1991-1999 for a sample of 67 firms in Taiwan. He used variables such as: the ratio of accumulated innovation patents to total accumulated patents, the ratio of the firm's R\&D expenditure to its total sales, the ratio of $\mathrm{R} \& \mathrm{D}$ employees to total employees. The results indicated that a higher ratio of publicly-supported $\mathrm{R} \& \mathrm{D}$ subsidies to total project expenditures would contribute to the firm growth of both sales and employment. Contrary to what one might expect, it also results in a decrease in the growth rate of employment in R\&D.

Deschryvere (2014) analysed how the relationship between R\&D and firm growth varies between continuous and occasional innovators for a sample of Finnish firms between 1998 and 2008. He found that only continuous product and process innovators show positive associations between $R \& D$ growth and sales growth. Also the links between sales growth and subsequent R\&D growth were stronger for continuous innovators than for occasional innovators, but only for product innovators. 
Segarra and Teruel (2014) analysed the impact of internal and external R\&D on firm's growth for a group of high-growth firms. Their results show that investing in $R \& D$ increases the likelihood of becoming a high-growth firm. Furthermore, internal and external $R \& D$ investments show varying impacts according to the firm growth distribution. Internal $R \& D$ shows a positive impact among highgrowth firms, while external $R \& D$ has a significant positive impact for firms with median growth rates.

Capasso et. al (2015) analysed the effect of R\&D expenditure on firm's employment growth in the medium term, using six cross-sectional waves of an innovation survey conducted in the Netherlands in all sectors. The analysis was focused on firms having positive $\mathrm{R} \& \mathrm{D}$ expenditure and investigates whether higher investments in $R \& D$ (in proportion to firm turnover) translate into higher medium-term growth rates. At all time terms, quantile regression techniques indicated that a higher $R \& D$ has a positive effect on high growers and allows a higher number of firms to be high growers. Still, once a firm invests in $R \& D$, even if a higher investment makes the firm more likely to have a very good performance, it does not make it less likely to have a bad one. They used the data from the Community Innovation Survey (CIS) that refer to the Netherlands, and from the Business Register (Algemeen Bedrijven Register-ABR) provided by the Dutch statistical office (Statistics Netherland-CBS). They considered the six waves of the innovation survey conducted between 1996 and 2006 and match them with yearly data from the Business Register from 1996 to 2011. With the linear regression model they estimated the average firm growth given the firm's R\&D intensity.

\section{Data and Methodology}

The aim of the article is to examine and quantify influence of $R \& D$ intensity, $\mathrm{R} \& \mathrm{D}$ investment and tax incentives on firms' growth in Portugal, Italy, Greece and Spain from 2002 to 2014. The empirical analysis is performed for PIGS countries, namely Portugal, Italy, Greece and Spain. The analysis uses data taken from OECD database and the EU Industrial R\&D Investment Scoreboard. Table 1 presents basic descriptive statistics of variables. 
Šeligová, M..: The Effects of R\&D Intensity and Tax Incentives on Firms Growth of PIGS Countries.

Tab. 1: Descriptive statistics of variables

\begin{tabular}{lrrrrrrr}
\hline Mean & 9,63 & 4,54 & 0,10 & 8,79 & 9,69 & 14715,22 & 5091,13 \\
Median & 8,70 & 2,67 & $-0,02$ & 5,64 & 9,02 & 3019,00 & 712,00 \\
$\begin{array}{l}\text { Standard } \\
\text { deviation }\end{array}$ & 16,05 & 8,17 & 0,19 & 11,55 & 19,77 & 36218,58 & 13612,21 \\
Maximum & 50,00 & 63,44 & 0,39 & 77,16 & 62,83 & 195086,00 & 73728,00 \\
Minimum & $-38,06$ & 0,06 & $-0,02$ & 0,21 & $-88,71$ & 301,00 & 44,00 \\
\hline
\end{tabular}

Source: Author's processing.

Tab. 2: Description of used variables

\begin{tabular}{ll}
\hline Abbreviation of variable & Description of variable \\
\hline G & $\begin{array}{l}\text { Depend variable: Growth of firms: Difference between sales in } \\
\text { present period and sales in previous period (\%) } \\
\text { R\&D Intensity: Ratio of R\&D investment to total sales (\%) } \\
\text { RDI }\end{array}$ \\
tax subsidy, the generosity of tax incentives: Measured as 1-B- \\
index \\
Capital Intensity: Ratio of R\&D investment to employee (EUR \\
million per employee) \\
Profitability: Ratio of profit to sales (\%) \\
FSI & Firm size: Number of employees R\&D \\
FSA & Firm sales (EUR million) \\
\hline
\end{tabular}

Source: Author's processing.

Before the implementation of a panel regression analysis it is needed to test the stationarity using each time series. It is a decision on the existence of a unit root. For this purpose, it was used Levin, Lin Chu test that demonstrated the time-series that are stationary. Due to this fact can be accomplished panel regression analysis. The estimates were made on the basis of the panel regression. There was used panel model with fixed effects. The data necessary for the fulfilment of these goals were obtained from the EU Industrial R\&D Investment Scoreboard that has been published within the context of the Industrial Research Monitoring and Analysis activities and OECD database. The data include countries such as Portugal, Italy, Greece and Spain for the 2002 - 2014 period. Vector of explanatory variables includes variables such as the (Table 2). The all data were examined on an annual basis from 2002 to 2014 
To identify factors affecting firms' growth will be estimated by following equation using panel regression analysis:

$$
\mathrm{G}_{\mathrm{it}}=\alpha_{0}+\sum_{i=1}^{n} \alpha_{\mathrm{i}} X_{i}^{G}+u_{t}^{G},
$$

Where $G_{i t}$ is the firms' growth of firms conducting firms in selected countries ${ }_{i}$ at time $t ; \alpha_{0}, \alpha_{i}$ shows the regression coefficients for firms growth; $X_{i}^{G}$ is a vector of explanatory variables for the firms' growth; $u_{t}^{G}$ represents an error component. Panel data are cross-section data that are collected at various points of time, but the data concern the same panel of subjects or objects in every period. In most studies, large cross-sections are found collected for only a few points of time. In an economic model there is one variable on the left-hand side of the equation, called the dependent variable. Variables on the right-hand side of the equation are the explanatory variables. The nature of economic variables can be endogenous, exogenous or lagged dependent. A variable is an endogenous variable if the variable is determined in the model in question. Therefore, the dependent variable is always an endogenous variable. The exogenous variables are determined outside the model. Lagged dependent (or lagged endogenous) variables are 'predetermined' in the model. In fact, they are endogenous, but their values have already been realised. Knowledge about the nature of the variables, especially of the explanatory variables, is of importance for the choice of an estimator for the unknown parameters and for knowing the properties of the estimator. (Vogelvang, 2005).

\section{Results and Discussion}

This part of the contribution focuses on the estimated results from the panel regression analysis including their comments. Using panel regression analysis, we have determined which variables affect the firms' growth and which do not. To estimate the factors affecting firms' growth the equation number 1 was used. First, we conducted a test of stationarity or the unit root test. The conducted tests stacionarity showed that we accept the null hypothesis when the time series contain a unit root and it is not stationary. Then we tested all considered variables. We used the results of diagnostic tests determining redundancy of parameters to reduce the number of explanatory variables. It was taken on information criteria including the Akaike criterion, Schwarz criterion and Hannan-Quinn criterion. We also focused on the values of the degree of correlation and statistical significance of individual variables. The aim of this contribution was to find a model with a high value of the adjusted coefficient of determination where all the variables model will be statistically significant. For estimating the linkages between firms' growth and selected factors (explanatory variables) was detected resulting equation estimating factors affecting firms' growth in Portugal, Italy, Greece and 
Spain from 2002 to 2014. The results of the panel regression analysis are included in table no 3.

\section{Tab. 3: Panel data estimations}

\begin{tabular}{lccc}
\hline & Coefficient & Std. Error & t-Statistics \\
\hline RDI & $0,254362^{*}$ & 0,607393 & 0,767088 \\
BI & $0,782339^{*}$ & 0,299778 & 2,127496 \\
\hline S.D. dependent var. & & 2,614952 & \\
S.E. of regression & & 4,567346 & \\
Adjusted R-squared & & 0,839985 & \\
Durbin-Watson stat & & 2,059 & \\
\hline Source: Author's calcution
\end{tabular}

Source: Author's calculations.

Note: * Denotes statistical significance at the $1 \%$ level.

Table no 3 shows the resulted relation between the effects selected variables and firms growth. Table no 3 shows that the estimated coefficients are positive and statistically significant at the $1 \%$ level. The results of the panel regression analysis indicate that the most important variables affecting the firms' growth are the R\&D intensity and generosity of tax incentives. These variables significantly influence the firms' growth. This finding confirms that increase of R\&D intensity and generosity of tax incentives contribute to the firms' growth.

The results show that the effect of R\&D intensity on firms' growth is significantly positive. This means that the increase (decrease) in $R \& D$ intensity will cause growth (decline) the firms' growth. This is consistent with study (Cohen and Levinthal, 1990).

Another statistically significant variable is the generosity of tax incentives represented as $\mathrm{R} \& \mathrm{D}$ tax credits. There was recorded a positive relation between the firms' growth and R\&D tax credits. This means that the increase (decrease) in R\&D tax credits will cause growth (decline) the firms' growth. In other words, the (positive) impact of the R\&D tax credits on the firm growth (as measured by the firm's net sales) increases with the level of the R\&D investment. This is consistent with study (Warda, 2009).

The obtained results suggest that an impact of generosity of tax incentives is higher and more intensive on firms' growth than impact of R\&D Intensity on firms' growth. The value of adjusted R-squared confirms the high explanatory power of the model. Its value is around $83 \%$. The results of Durbin-Watson test point out the quality of the model by indicating that the residues are not burdened autocorrelation. 


\section{Conclusion}

Research and development (R\&D), including innovation is important for economic growth, competitiveness and growing standards of living. We must pay much more attention to this part of the economy. Every single country finances its $R \& D$ in a different way. Some of the countries spend a huge amount of money on its $R \& D$ and on the other hand there are other countries that spend less money and therefore they put less emphasis on their research. Research in the developed societies has an irreplaceable position. Science, technologies, innovations are changing and transforming and they are adapting to the current challenges as well as other areas of social life. These new values strengthen the competitiveness of the economy, which also represents one of the government's priorities.

The aim of this paper is to evaluate the effects of R\&D intensity and tax incentives on firms' growth in Portugal, Italy, Greece and Spain from 2002 to 2014. The focus of this paper is to identify which selected factors affecting firms' growth. The effect of variables such as the R\&D intensity, generosity of tax incentives, capital intensity, profitability, firm's size and firm sales was tested. The results of the panel regression analysis showed that the firms's growth affected mainly R\&D intensity and generosity of tax incentives. The model results showed a positive effect of R\&D intensity and generosity of tax incentives at firms' growth. Other variables were not statistically significant.

\section{Acknowledgement}

This paper ensued thanks to the support of the grant SGS/17/2015 "Financial instruments of public support for research and development in the European Union".

\section{References}

Aghion, P., Howitt, P., 1992. A model of growth through creative destruction. Econometrica 2, 323.

Benhabib, J., Jovanovic, B., 1991. Externalities and growth accounting. American Economic Review 1, 82-113.

Castro, C., 2006., Política Fiscal e Crescimento Económico. Polytechnical Studies Review 5/6, 087-118.

Capasso, M., Treibich, T., Vespagen, B., 2015. The medium-term effect of R\&D on firm growth. Small Business Economics 1, 39-62.

Cefis, E., Orsenigo, L., 2001. The persistence of innovative activities; a cross country and cross-sectors comparative analysis. Research Policy 30, 1139-1158.

Coad, A., Rao, R., 2008. Innovation and firm growth in hightech sectors: A quantile regression approach. Research Policy 37, 633-648. 
Coad, A., 2009. The growth of firms: A survey of theories and empirical evidence. Edward Elgar, Cheltenham.

Coad, A., Rao, R., 2010. Firm growth and R\&D expenditure. Economics of Innovation and New Technology 2, 127-145.

Cohen, W. M., Levinthal, D., 1989. Innovation and learning: The two faces of R\&D. The Economic Journal 397, 569-596.

Cohen, W., Levinthal, D., 1990. Absorptive capacity: a new perspective on learning and innovation. Administrative Science Quarterly 35, 128-152.

Delmar, F., Davidsson, P., Gartner, W., 2003. Arriving at the high-growth firm. Journal of Business Venturing 18, 189-216.

Del Monte, A., Papagni, E., 2003. R\&D and the growth of firms: empirical analysis of a panel of Italian firms. Research Policy 6, 1003-1014.

Demirel, P., Mazzucato, M., 2012. Innovation and firm growth: Is R\&D worth it? Industry and Innovation 1, 45-62.

Deschryvere, M., 2014. R\&D, firm growth and the role of innovation persistence: analysis of Finnish SMEs and large firms. Small Business Economics 4, 767-785.

Elschner, Ch., Ernst, Ch., 2008. The The Impact of R\&D Tax Incentives on R\&D Costs and Income Tax Burden. Discussion Paper No. 08-124.

García-Manjón, J., Romero-Merino, M., 2012. Research, development, and firm growth: Empirical evidence from European top R\&D spending firms. Research Policy 41, 1084-1092.

Greenhalgh, C., Rogers, M., 2006. The value of innovation: The interaction of competition, R\&D and IP. Research Policy 4, 562-580.

Hall, B. H., 1987. The relationship between firm size and firm growth in the US manufacturing sector. The Journal of Industrial Economics 4, 583.

Hall, B., Mairesse, J., 1995. Exploring the relationship between R\&D and productivity in French manufacturing firms. Journal of Econometrics 1, 263-293.

Hölzl, W., 2009. Is the R\&D behaviour of fast-growing SMEs different? Evidence from CIS III data for 16 countries. Small Business Economics 33, 59-75.

Hölzl, W., Friesenbichler, K. S., 2010. High-growth firms, innovation and the distance to the frontier. Economics Bulletin 2, 1016-1024.

Huergo, E., Jaumandreu, J., 2004. Firms' age, process innovation and productivity growth. International Journal of Industrial Organisation 22, 541-559.

Huergo, E., Moreno, L., 2011. Does history matter for the relationship between $\mathrm{R} \& \mathrm{D}$, innovation, and productivity? Industrial and Corporate Change 5, 13351368 
Lee, C.Y., 2009. Competition favors the prepared firm: Firms R\&D responses to competitive market pressure. Research Policy 38, 861-870.

Lian, Y., Foley, M., Liu, X., Lu, J., 2011. The Role Of R\&D In Improving Firm Growth: Evidence From High-TeCh Companies In China. International Journal of Business and Economics Perspectives 1, 108-124.

Peková, J. et al., 2008. Veřejná správa a finance veřejného sektoru. ASPI, Praha, 712. ISBN 978-80-7357-351-5.

Segarra, A., Teruel, M., 2014. High-growth firms and innovation: An empirical analysis for Spanish firms. Small Business Economics 4, 355-373.

Stiglitz, J., 1969. Theory of innovation: Discussion. American Economic Review 2, 46-49.

Straathof, B. et. al., 2014. A study on R\&D Tax Incentives. Final Report of the Netherlands Bureau for Economic Policy Analysis, The Hague.

Triguero-Cano, A., Cuerva Narro, M. C., Corcoles Gonzalez, D., 2012. Persistence of innovation and firm's growth: Evidence from a panel of Spanish manufacturing firms. Paper presented at the "Firm Growth and Innovation" workshop, Tarragona, 28-29 June 2012.

Triguero, A., Cuerva. M., Córcoles, D., 2014. Persistence of innovation and firm's growth: Evidence from a panel of SME and large Spanish manufacturing firms. Small Business Economics 4, 1-18.

Varadzin, F. et al., 2004. Ekonomický rozvoj a růst. Professional Publishing, Praha, 329. ISBN 80-86419-61-4.

Vogelvang, B., 2005. Econometrics - Theory and Applications with Eviews. Prentice Hall. Financial Times. Pearson Education Limited. Edinburgh Gate, Harlow, England. ISBN 0-273-68374-8.

Wang, H. K., 2013. The Effect of R\&D Subsidies on Firm Growth in Taiwan. International Journal of Economic Perspectives 2, 11-23.

Warda, J., 2009. An Update of R\&D Tax Treatment in OECD Countries and Selected Emerging Economies, 2008-2009.

Wong, P. K., Ho, Y. P., Autio, E., 2005. Entrepreneurship, innovation and economic growth: Evidence from GEM data. Small Business Economics 3, 335350 . 
